\title{
Porto-systemic Shunt Due to Superior Vena Cava Obstruction Caused by A Haemodialysis Catheter: A Rare Presentation
}

\section{Hemodializ Kateterine Bağlı Vena Kava Superior Obstrüksiyonu Sonucu Oluşan Portosistemik Şant: Nadir Prezentasyon}

(D) Yasemin Durum Polat, (D) Amir Hossein Navaei, (D) Kutsi Köseoğlu

Aydın Adnan Menderes University Faculty of Medicine, Department of Radiology, Aydın, Turkey

Keywords

Superior vena cava obstruction, systemicto-portal shunt, "hot spot" sign

\section{Anahtar Kelimeler}

Vena kava süperior obstruksiyonu, portosistemik şant, "hot spot" işareti

Received/Geliş Tarihi : 23.04.2016

Accepted/Kabul Tarihi : 24.06.2016

doi:10.4274/meandros.galenos.2016.2823

Address for Correspondence/Yazışma Adresi: Yasemin Durum Polat Assistant Professor, Aydın Adnan Menderes University Faculty of Medicine, Department of Radiology, Aydın, Turkey

Phone : +90 5052291535

E-mail : yasemindurum@gmail.com

ORCID ID: orcid.org/0000-0002-4452-6632

(C) Meandros Medical and Dental Journal, Published by Galenos Publishing House.

This is article distributed under the terms of the

Creative Commons Attribution NonCommercial 4.0

International Licence (CC BY-NC 4.0).

\begin{abstract}
In patients with superior vena cava (SVC) obstruction, arterial phase focal contrast enhancement of the left lobe of the liver might be observed upon computed tomography (CT). Herein, we present the case of a 52-year-old patient with SVC obstruction with an area of increased contrast enhancement (or hot spot sign) within the left lobe of the liver due to the formation of collateral circulation detected via multi-detector $\mathrm{CT}$ using multiplanar and three-dimensional volume imaging techniques. With this case, we aimed to emphasise that abnormal arterial phase enhancement of the left lobe of the liver might be observed upon CT in patients with SVC obstruction and should not be misinterpreted as a hepatic lesion or metastasis. The importance of this case is that it shows how to differentiate CT findings of focal contrast enhancement of the liver due to venous shunt formation from those of metastasis in patients with a high risk of liver metastasis.
\end{abstract}

Öz

Vena kava süperior'nun (VKS) kronik obstrüksiyonunda venöz drenaj için ana kolleteral yollar gelişir. Bu durumun nadir görülen nedenlerinden biri katetere bağlı kronik obstrüksiyondur. Bu hastalarda bilgisayarlı tomografide (BT), arteryel fazda karaciğer sol lobunda fokal kontrast tutulumu görülebilir. Fokal kontrast tutulumu obstruksiyon sonucu gelişen VKS ve portal ven arasında görülen portosistemik şanta bağlıdır. Diğer bir adı "hot spot işareti" olarak bilinen görünüm özellikle onkolojik hastalarda metastazla karışabilmektedir. Biz burada mesane tümörü tanılı 52 yaşındaki olgumuzda nadir bir neden olan hemodiyaliz kateterinin yol açtığı VKS obstrüksiyonu sonucu oluşan karaciğer sol lobundaki fokal kontrast tutulumunun çok kesitli BT ile elde olunan üç planda izlenen görüntülerini sunmayı ve oluşan diğer kolleteral yolları tekrar gözden geçirmeyi amaçladık. 


\section{Introduction}

Venous flow blockage of superior vena cava (SVC) leads to the formation of venous collateral pathways, including systemic to portal shunts that could cause hepatic venous stasis. According to the literature there are some major collateral pathways are as following; 1 - the azygos- hemiazygos, 2- the internal mammarian vein, 3 - the lateral thoracic, 4- superficial thoraco-abdominal and 5- vertebral venous plexus. The internal mammarian and lateral thoracic veins drain in to the superficial epigastric and paraumblical veins and ultimately to the portal venous system (14). However sometimes via musculophrenic vein collaterals venous congestion occurs in the liver area next to the intersection of the right and left lobes, which leads to abnormal enhancement of fourth segment of the left hepatic lobe (5-7). In this case we present a patient with SVC occlusion with an area of focal increased contrast enhancement (or "hot spot sign") detected on multi-detector computed tomography (CT) due to formation of collateral circulation in the left lobe of the liver using multiplanar and 3D volume image techniques.

\section{Case Report}

Patient consent was not obtained because the evaluation was retrospective. Our case is a 52-year-old man with known bladder malignancy who have been taking chemotherapy and hemodialysis treatment through permanent hemodialysis catheter. Thoracoabdominal contrast-enhanced CT was obtained to evaluate the response to treatment. CT imaging revealed thrombosis of the hemodialysis catheter, formation of venous collaterals in the anterior chest wall as a result of occlusion of SVC. Although the first CT images of our patient revealed only a slight focal contrast enhancement in the fourth segment of hepatic left lob, the follow up CT scan images acquired just two months later showed a more prominent and larger contrast enhanced area in the fourth segment of the liver in the early arterial phase, which was associated with focal hepatic "hot spot" sign, due to collateral drainage (Figure 1-4).

\section{Discussion}

In case of SCV occlusion, occasionally in CT imaging, areas of focally increased blood flow in the left hepatic lobe may be seen due to collateral vein formation. This appears as an abnormal hyperattenuation of the left hepatic lobe in arterial or early portal phase. This is a result of porto-systemic venous shunt between the SCV and portal vein $(1,2)$.

In case of chronic obstruction of caval system, collateral pathways develop to maintain venous drainage. The major collateral pathways are well described and include; the azygos-hemiazygos, external and internal mammary, lateral thoracic, and vertebral pathways.

There are several unusual collateral pathways such as; systemic to cavo-portal, pulmonary venous and intrahepatic collateral pathways. Four cavoportal pathways have been described. One of which is caval-superficial-umblical-portal pathway in which the epigastric veins anastomose with internal or external mammary veins. These veins following a
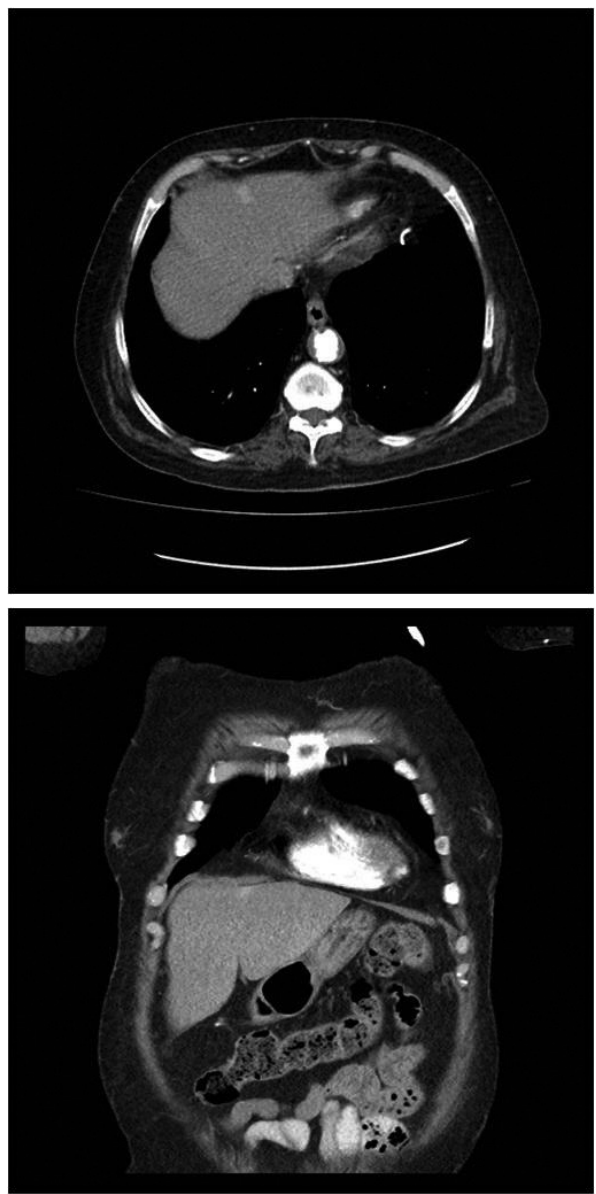

Figure 1, 2. Contrast-enhanced axial and coronal computed tomography shows a slight contrast enhancement area in the fourth segment of hepatic left lobe 
recanalized paraumblical vein drain in a hepato-pedal fashion into the left portal vein (3). The collateral venous pathway comprises the internal mammary and paraumblical veins, leading to formation of a "hot spot" due to high blood flow around the area of union of the paraumblical vein and the left main branch of the portal vein $(4,5)$. An intense focal hepatic enhancement on abdominal CT has been reported (6). Sometimes, abnormal focal enhancement in contrast-enhanced CT or focal increased radiotracer uptake in Tc-99m sulfur colloid scan has been called the "focal hepatic hot spot sign" $(4,5,7)$. Especially in the cancer patients first imaging findings (in our case
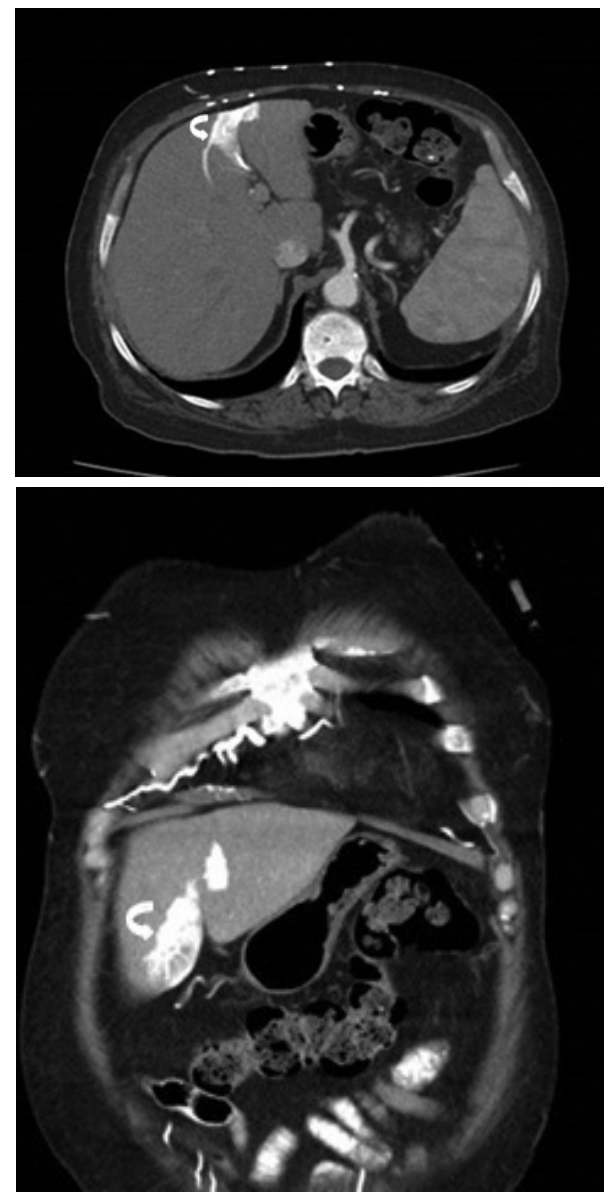

Figure 3, 4. Axial and coronal computed tomography (CT) scan of upper abdomen demostrates hypervasculer area in segment IV of liver that represents CT counterpart of focal hot spot sign. Notice enlarged anterior chest wall collateral vessels (curve arrows) with SVC obstruction. Contrast-enhanced CT image shows reflux of contrast material into hepatic vein (arrow)

SVC: Superior vena cava
Figures 1, 2) might be misinterpreted as metastasis. However, the location of the lesion and the presence of collateral vascular structures should be a clue for "hot spot sign".

In conclusion, flaming focal arterial phase enhancement of hepatic left lobe in CT scans might be seen in case of SVC occlusion, and is described as the focal hepatic "hot spot" sign. It should not be misinterpreted as a hepatic lesion or metastasis.

\section{Ethics}

Informed Consent: Patient consent was not obtained because the evaluation was retrospective.

Peer-review: Internally peer-reviewed.

\section{Authorship Contributions}

Concept: K.K., Design: K.K., Y.D.P., Data Collection or Processing: Y.D.P., A.H.N., Analysis or Interpretation: Y.D.P., Literature Search: Y.D.P., Writing: Y.D.P.

Conflict of Interest: No conflict of interest was declared by the authors.

Financial Disclosure: The authors declared that this study received no financial support.

\section{References}

1. Grayet D, Ghaye B, Szapiro D, Dondelinger RF. Systemic-topulmonary venous shunt in superior vena cava obstruction revealed on dynamic helical CT. AJR Am J Roentgenol 2001; 176: 211-3.

2. Maldjian PD, Obolevich AT, Cho KC. Focal enhancement of the liver on CT: a sign of SVC obstruction. J Comput Assist Tomogr 1995; 19: 316-8.

3. Kapur S, Paik E, Rezaei A, Vu DN. Where there is blood, there is a way: unusual collateral vessels in superior and Inferior vena cava obstruction. Radiographics 2010; 30: 67-78.

4. Muramatsu T, Miyamae T, Mashimo M, Suzuki K, Kinoshita $S$, Dohi Y. Hot spots on liver scans associated with superior or inferior vena caval obstruction. Clin Nucl Med 1994; 19: 622-9.

5. Breen DJ, Rutherford EE, Stedman B, Lee-Elliott C, Hacking CN. Intrahepatic arterioportal shunting and anomalous venous drainage: understanding the CT features in the liver. Eur Radiol 2004; 14: 2249-60.

6. Baba Y, Ohkubo K, Nakai H, Hamada K, Hokotate H, Nakajo M. Focal Enhanced Areas of the Liver on Computed Tomography in a Patient with Superior Vena Cava Obstruction. Cardiovasc Intervent Radiol 1999; 22: 69-70.

7. Dickson AM. The focal hepatic hot spot sign. Radiology 2005; 237: 647-8. 